\title{
Scolex morphology of monozoic cestodes (Caryophyllidea) from the Palaearctic Region: a useful tool for species identification
}

\author{
Mikuláš Oros ${ }^{1,2}$, Tomáš Scholz ${ }^{2}$, Vladimíra Hanzelová ${ }^{1}$ and John S. Mackiewicz ${ }^{3}$ \\ ${ }^{1}$ Parasitological Institute, Slovak Academy of Sciences, Hlinkova 3, 04001 Košice, Slovakia; \\ ${ }^{2}$ Institute of Parasitology, Biology Centre of the Academy of Sciences of the Czech Republic, Branišovská 31,37005 České \\ Budějovice, Czech Republic; \\ ${ }^{3}$ State University of New York at Albany, New York 12222, USA
}

\begin{abstract}
A comparative study of the scoleces of caryophyllidean tapeworms (Cestoda: Caryophyllidea), parasitic in cypriniform fishes in the Palaearctic Region, was carried out using light and scanning electron microscopy. Three-dimensional pictures of the scoleces of 18 species of caryophyllidean cestodes of the Capingentidae (1 species), Caryophyllaeidae (7) and Lytocestidae (10), and outlines of the scoleces and anterior extent of the testes and vitelline follicles of 19 Palaearctic taxa were documented. Both species of Atractolytocestus Anthony, 1957 possess a bulboacuminate scolex, whereas species of Archigetes Leuckart, 1876 have fossate scoleces of the bothrioloculodiscate type, with loculi, bothrium-like depressions and an apical disc. Breviscolex orientalis Kulakovskaya, 1962, the only member of the Capingentidae, has a cuneiform scolex, as do both taxa of the lytocestid genus Caryophyllaeides Nybelin, 1922. The scoleces of two species of Caryophyllaeus Gmelin, 1790 are flabellate, whereas that of the congeneric C. fimbriceps Annenkova-Chlopina, 1919 is cuneicrispitate. Khawia Hsü, 1935, the most specious Palaearctic genus, with seven taxa that we consider to be valid, has the highest diversity in scolex morphology: semi-bulbate, flabellate, cuneiform, cuneifimbriate, truncated cuneiform-flabellate and festoon-like. Species of Monobothrium Nybelin, 1922 have either a digitiform scolex with widened posterior part or cuneiform, with lateral auricular extensions. Paracaryophyllaeus gotoi (Motomura, 1927) is characteristic in its possessing a bulbate scolex, whereas Paraglaridacris limnodrili (Yamaguti, 1934) has a fossate scolex of the bulboloculate type with bothrium-like depressions and feebly developed lateral loculi. Anterior extent of the testes and vitelline follicles and their mutual position show a somewhat higher variability than scolex shape, with intraspecific variation in some taxa, such as Atractolytocestus sagittatus (Kulakovskaya et Akhmerov, 1965), B. orientalis, Khawia armeniaca (Cholodkovsky, 1915) and K. sinensis Hsü, 1935. Based on scolex morphology and relative position of the anterior testes and vitelline follicles, a key is provided to facilitate the routine identification of 20 Palaearctic caryophyllidean taxa.
\end{abstract}

Keywords: Cestoda, fish, comparative morphology, scanning electron microscopy, identification, Palaearctic Region

Caryophyllidean tapeworms (Platyhelminthes: Eucestoda) represent a widely distributed group of intestinal parasites of cypriniform and siluriform fishes occurring in all zoogeographical regions except the Neotropics (Mackiewicz 1994). They are unique among "true" cestodes (Eucestoda) in their possession of a monozoic or monopleuroid body type, which is astrobilate and consists of only a single set of male and female organs. Some caryophyllideans, especially those in carp and related cyprinids cultured in fishponds, may be pathogenic for their fish hosts (Bauer et al. 1973, Williams and Jones 1994, Oros et al. 2009).

Caryophyllideans possess a simple scolex, the morphology of which has been suggested to provide characteristics useful for generic classification (Mackiewicz 1972, 1981, 1994), and also in some cases for species identifica- tion (Kulakovskaya 1961, Dubinina 1987, Scholz 1989). However, the use of scolex morphology in identification can be limited because the scoleces of these cestodes are highly motile and thus can change considerably in shape. In addition, the shape and size of the scolex depends to a great extent on processing methods, in particular fixation of worms.

Over the course of a long-term research project on the helminth parasites of freshwater fishes, extensive material of caryophyllideans was collected from fishes of the families Cyprinidae and Cobitidae (Cypriniformes) and Odontobutidae (Perciformes) in the Palaearctic Region. Since these cestodes were processed using the same method to ensure comparability of morphological and biometrical data, this procedure enabled us to perform a large-scale comparative study on scolex morphology. In addition, it 
also made it possible to assess the use of scolex characters and the anteriormost extent of the testes and vitelline follicles for the differentiation of caryophyllidean taxa and to make a simple key to facilitate species identification.

\section{MATERIALS AND METHODS}

Newly collected specimens of 14 species (see the list below) for light (LM) and scanning electron microscopical (SEM) observations were isolated from the intestine of freshly killed fish hosts, rinsed in saline, fixed immediately with $4 \%$ hot (almost boiling) formaldehyde solution (= formalin) and transferred to $70 \%$ ethanol after 1-2 weeks. For light microscopy, specimens were processed by the methods of Scholz and Hanzelová (1998): stained with Schuberg's hydrochlorid carmine, destained in $70 \%$ acid ethanol (i.e. ethanol with several drops of $\mathrm{HCl}$ ), dehydrated through a graded ethanol series, clarified in clove oil, and mounted in Canada balsam as permanent preparations.

Drawings were made using a drawing attachment on an Olympus BX51 microscope with the use of Nomarski interference contrast. Measurements were taken using Olympus Image-Pro programme. For SEM studies, specimens were dehydrated through a graded ethanol series, followed by a graded amylacetate series, dried by critical-point method, sputtered with gold and examined with a JEOL JSEM 7401F microscope. Stubs with scoleces are deposited in the Laboratory of Helminthology of the Institute of Parasitology; most voucher specimens of newly collected material are deposited in the Helminthological Collection, Institute of Parasitology, České Budějovice, Czech Republic (acronym IPCAS; http://www.paru.cas.cz).

Since some taxa were not available in the authors' collections, material of the following caryophyllidean species from museum collections was also studied (collection acronyms are as follows: The Natural History Museum, London, UK - BMNH; Institute of Zoology, St. Petersburg, Russia - IZSP; Parasitological Institute SAS, Košice, Slovakia - PISAS; species for which material fixed with hot formalin was available are marked with an asterisk):

Family Capingentidae

1. *Breviscolex orientalis Kulakovskaya, 1962 - eight specimens from Hemibarbus barbus (Temminck et Schlegel), Biwa Lake, Japan (IPCAS C-219/1, 2).

Family Caryophyllaeidae

2. *Archigetes sieboldi Leuckart, 1878 - six specimens from Cyprinus carpio L., Tisa River, Slovakia (PISAS 17/08a, b, 20/08a, b, 33/08), three specimens from C. carpio, Vodňany, Czech Republic (IPCAS C-45/2), and two specimens from Gnathopogon elongatus (Temminck et Schlegel), Suwa Lake, Japan (IPCAS C-45/1).

3. *Caryophyllaeus brachycollis Janiszewska, 1951 - five specimens from Abramis sapa (Pallas), Tisa River (PISAS 193/04a, b) and three specimens from Barbus meridionalis Risso, Myslavský Creek near Košice, Slovakia (PISAS 2M/05, $6 \mathrm{M} / 05 \mathrm{a}, \mathrm{b})$.

4. Caryophyllaeus fimbriceps Annenkova-Chlopina, 1919 three specimens from Cyprinus carpio, Russia (IZSP 13693a, b, 13608) and Germany (BMNH 1995.2.13.503), and from Tinca tinca (L.), Vltava River, Czech Republic (IPCAS C-3/3).

5. *Caryophyllaeus laticeps (Pallas, 1781) - ten specimens from Abramis brama (L.), Tisa River, Slovakia (PISAS 77/04, 80/04, 147/04, 182/04, 184/04, 188/04).
6. Monobothrium wageneri Nybelin, 1922 - four specimens from Tinca tinca, Labe (Elbe) River, Czech Republic and four specimens from T. tinca (all hosts Cyprinidae), Bracciano Lake, Italy (IPCAS C-206/1).

7. *Paracaryophyllaeus gotoi (Motomura, 1927) - one specimen from Cobitis taenia L. (Cobitidae), Latorica River, Slovakia (PISAS 458/04) and two specimens, Kötelek, Hungary (IPCAS C-218/1).

8. *Paraglaridacris limnodrili (Yamaguti, 1934) - one specimen from Perccottus glenii Dybowski (Odontobutidae) (accidental host), Latorica River, Slovakia (PISAS 28/05).

Family Lytocestidae

9. *Atractolytocestus huronensis Anthony, 1958 - 12 specimens from Cyprinus carpio, Tisa and Latorica Rivers, Slovakia (PISAS 8/02, 12/02, 11/05, 263/06, 82/07, 182/07, 110/08).

10. *Atractolytocestus sagittatus (Kulakovskaya et Akhmerov, 1965) - 10 specimens from Cyprinus carpio, Suwa Lake and Biwa Lake, Japan (IPCAS C-340/1).

11. *Caryophyllaeides ergensi Scholz, 1990 - eight specimens from Tribolodon hakonensis (Günther), Ogawara Lake, Japan (IPCAS C-217/1)

12. *Caryophyllaeides fennica (Schneider, 1902) - eight specimens from Rutilus rutilus (L.), Tisa River, Slovakia (PISAS 18/04, 298/05a, b).

13. Khawia armeniaca (Cholodkovsky, 1915) - two specimens from Capoeta damascina (Valenciennes), Zayande (Zaindeh) River at Esfahan, Iran (BMNH 1979.9.27.1-10), one specimen from Coregonus sp., Sevan Lake, Armenia (no voucher), one specimen from Barbus barbulus (IPCAS C-48/4) and one specimen from B. grypus (IPCAS C-48/2), Iraq.

14. Khawia baltica Szidat, 1941 - four specimens from Tinca tinca, Břehyně, Czech Republic (IPCAS C-42/1).

15. *Khawia japonensis (Yamaguti, 1934) - five specimens from Cyprinus carpio, Biwa Lake, Hahima and Gifu, Japan (IPCAS C-348/1).

16. Khawia parva (Zmeev, 1936) - six specimens from Carassius carassius (L.) and C. auratus (L.), Amur River and Bolon Lake, Russia (IZSP 1461, 1462, 1463, 1466).

17. *Khawia rossittensis (Szidat, 1937) - eight specimens from Carassius auratus, Tisa and Latorica Rivers, Slovakia (PISAS 43/02, 8/03, 81/05, 95/05, 271/05, 554/05).

18. *Khawia saurogobii Xi, Oros, Wang, Wu, Gao et Nie, 2009 - 12 specimens from Saurogobio dabryi Bleeker, Yangtze River, Wuhan, China (IPCAS 58/09 WU, 61/09 WU, 62/09 WU, 63/09 WU, 470/09 WU).

19. *Khawia sinensis Hsü, 1935 - 12 specimens from Cyprinus carpio (all hosts Cyprinidae), Latorica River and Vel'ký Kamenec water reservoir, Slovakia (PISAS 111/08, 53/09 1-10).

No specimens of Caryophyllaeus syrdarjensis Skrjabin, 1913, described from the barbel Schizothorax intermedius McClelland, 1842 from Turkestan, Monobothrium auriculatum Kulakovskaya, 1961 from Leuciscus danilewskyi (Kessler) from Ukraine, Archigetes brachyurus Mrázek, 1908 from tubificids (Annelida: Oligochaeta) and cyprinid fishes from the former Czechoslovakia, and A. cryptobothrius Wisniewski, 1928 from tubificids from Poland were available.

Terminology of scolex types is largely based on that proposed by Mackiewicz for caryophyllideans (1994 - see his figs. 5.1-5.21), but other morphological descriptors were used if necessary to better characterise scolex shape. In general, these additional terms are in common use in the literature. 


\section{RESULTS}

Three-dimensional scanning electron micrographs (SEM) of the scoleces of 18 species of caryophyllidean cestodes of the Capingentidae (1 species), Caryophyllaeidae (7), and Lytocestidae (10) are presented in Fig. 1. Outlines of the scoleces and anterior extent of the testes and vitelline follicles are shown in Figs. 2 and 3.

Both species of Atractolytocestus Anthony, 1958, A. huronensis and A. sagittatus, possess a bulboacuminate scolex (Fig. 1A-C), but they differ from each other in the length of the neck and mutual position and anteriormost extent of the testes and vitelline follicles (Fig. 2A-C). Species of Archigetes Leuckart, 1876 (only one species available and illustrated) possess fossate scoleces of the bothrioloculodiscate type, with loculi, bothrium-like depressions and an apical disc (Figs. 1D, 2D). Individual species can be distinguished by anterior extent of the testes and vitelline follicles (Fig. 2D; see also figures in Kennedy 1965). Breviscolex orientalis, the only member of the Capingentidae, has a cuneiform scolex (Figs. 1E, 2E), as do both taxa of the lytocestid genus Caryophyllaeides Nybelin, 1922, C. ergensi and C. fennica (Figs. 1F, G, 2F, G). The scoleces of two species of Caryophyllaeus Gmelin, 1790, C. brachycollis and C. laticeps, are flabellate (Figs. 1H, J, 2H, J), whereas that of the congeneric $C$. fimbriceps is cuneicrispitate (Figs. 1I, 2I).

The highest diversity in scolex morphology is found in species of Khawia Hsü, 1935, the most specious Palaearctic genus with seven taxa we consider to be valid (unpublished data). Khawia armeniaca possesses a semi-bulbate scolex (Figs. 1K, 3A; no hot formalin-fixed specimens available), whereas that of $K$. baltica is flabellate (Figs. $1 \mathrm{~L}, 3 \mathrm{~B}$; based on flattened specimens). Khawia japonensis has a cuneifimbriate scolex (Figs. 1M, 3C), whereas the scolex of $K$. sinensis is festoon-like (Figs. 1Q, 3G) and that of $K$. rossittensis is cuneiform (Figs. 1N, 3E). Khawia parva (Fig. 3D) has a cuneiform scolex expanded laterally (almost flabellate), but hot formalin-fixed material was not available. The scolex of $K$. saurogobii is truncated cuneiform-flabellate (Figs. 1O, P, 3F).

Monobothrium wageneri, for which hot formalin-fixed material was not available, has a digitiform scolex, widened posteriorly (Figs. 1R, 3I), whereas M. auriculatum (no material available) possesses a cuneiform scolex, with lateral auricular extensions (Fig. $3 \mathrm{H}$; according to Kulakovskaya 1961). Paracaryophyllaeus gotoi is characteristic in possessing a bulbate scolex (Figs. 1S, 2K) and Paraglaridacris limnodrili has a fossate scolex of the bulboloculate type (Fig. 1T).

Anterior extent of the testes and vitelline follicles and their mutual position show a somewhat higher variability than scolex shape, with intraspecific variation in some taxa, such as A. sagittatus (Fig. 2B, C). Similar variation can be found in B. orientalis, $K$. armeniaca and $K$. sinensis (data not shown). However, this variation is low, species-specific in other taxa and thus enables good differentiation of individual species, including those of Caryophyllaeus (Fig. 2H-J) and Khawia (Fig. 3A-G). Unlike scolex shape, which is fairly similar, anterior extent of the testes and vitelline follicles is a suitable diagnostic feature of otherwise morphologically almost identical species of Atractolytocestus. In A. huronensis, the testes begin posterior to anteriormost vitelline follicles (Fig. 2A), whereas they begin anterior to the first vitelline follicles in $\mathrm{A}$. sagittatus (Fig. 2B, C).

On the basis of the present data on scolex morphology and anterior extent of the testes and vitelline follicles, a preliminary key to facilitate routine identification of caryophyllideans from Palaearctic cyprinid and cobitid fishes is provided. However, reliable identification of some taxa may require other morphological characters, especially those related to the anterior extent of uterine loops, shape of the ovary, relative size of the cirrus-sac and other characteristics (see Scholz 1989, Protasova et al. 1990).

\section{A preliminary key to the species of the Caryophyllidea from the Palaearctic Region based on scolex morphology and anterior extent of testes and vitelline follicles:}

1a. Scolex fossate, i.e. with loculi or bothrium-like depressions (Fig. 1D, T) ........................................... 2

1b. Scolex afossate, i.e. without loculi or bothrium-like depressions (Fig. 1A-C, E-S) ............................. 3

2a. Scolex bulboloculate (Fig. 1T) ......... Paraglaridacris limnodrili (Yamaguti, 1934) Scolex nearly spherical, with a pair of deep median and two lateral shallow loculi (Fig. 1T).

2b. Scolex bothrioloculodiscate (Fig. 1D) Archigetes sieboldi Leuckart, 1878 Scolex slightly widened before neck region, with dorsal and ventral bothrium-like depressions and sublateral loculi, and with apical disc (Fig. 1D); testes begin anterior to vitelline follicles (Fig. 2D).

Remarks: Kennedy (1965) provided identification key to species of Archigetes; they are mainly differentiated by the anterior extent of the testes and vitelline follicles.

3a. Scolex bulbate or semi-bulbate (Fig. 1K, S) ......... 4

3b. Scolex bulboacuminate (Fig. 1A-C) .................... 5

3c. Scolex cuneiform (Figs. 1E-G, N, 2H) ................. 6

3d. Scolex truncated cuneiform-flabellate (Fig. 1O, P) Khawia saurogobii

Xi, Oros, Wang, Wu, Gao et Nie, 2009

Scolex short and markedly wider than neck, with shallow dorsal and ventral superficial grooves (Fig. 1O, P); vitelline follicles and testes begin immediately posterior to scolex, at approximately same level (Fig. 3F).

3e. Scolex with fimbriate anterior margin (cuneifimbriate, festoon-like or cuneicrispitate) (Fig. 1I, M, Q)

10

3f. Scolex flabellate, with smooth anterior margin (Fig. 1H, J, L) ....................................................11 


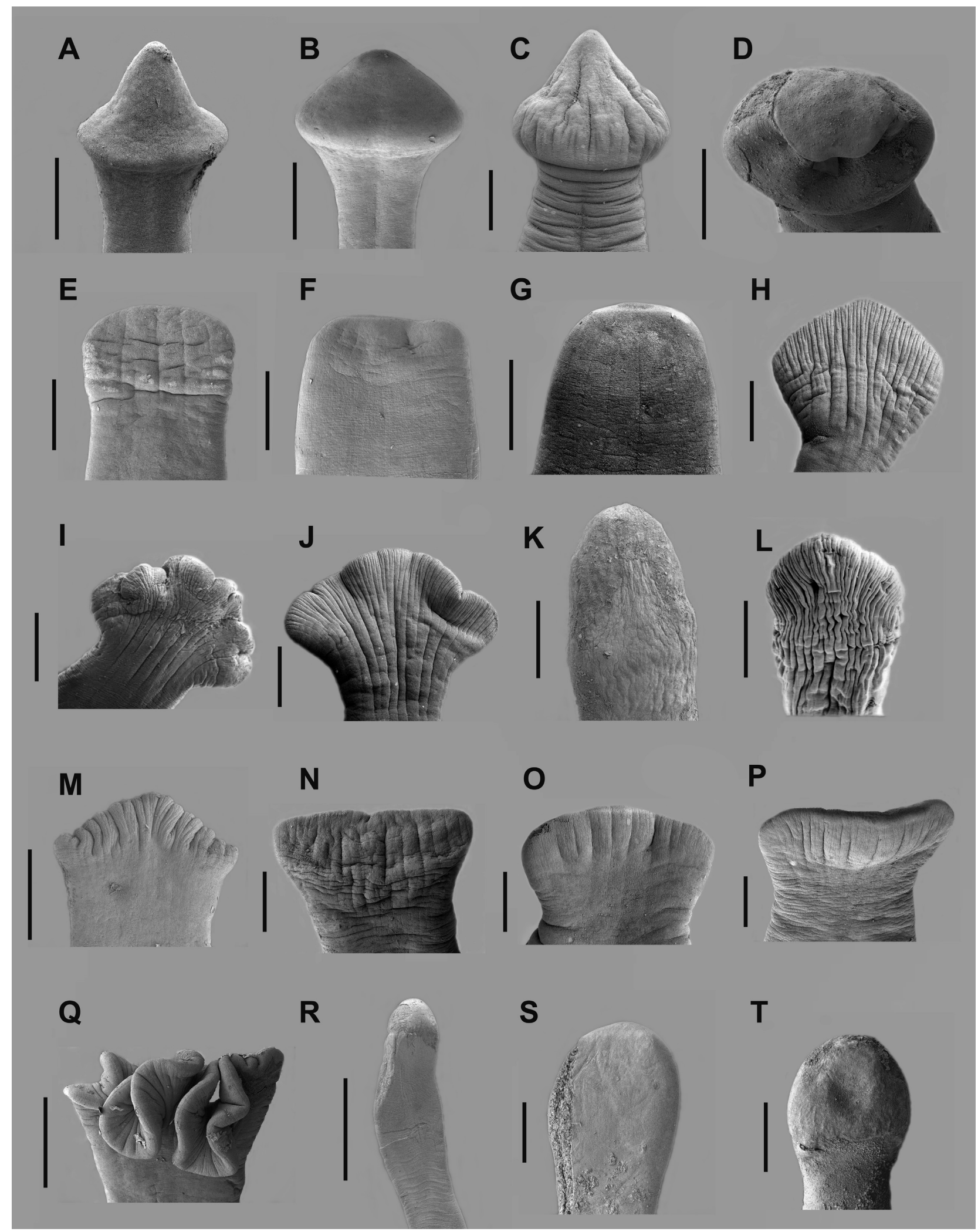

Fig. 1. Scanning electron micrographs of the scoleces of Palaearctic species of Caryophyllidea. A - Atractolytocestus huronensis; B, C - Atractolytocestus sagittatus; D - Archigetes sieboldi $\mathbf{E}$ - Breviscolex orientalis; $\mathbf{F}$ - Caryophyllaeides ergensi; $\mathbf{G}-$ Caryophyllaeides fennica; $\mathbf{H}$ - Caryophyllaeus brachycollis; I - Caryophyllaeus fimbriceps; J - Caryophyllaeus laticeps; $\mathbf{K}-$ Khawia armeniaca; $\mathbf{L}$ - Khawia baltica; $\mathbf{M}$ - Khawia japonensis; $\mathbf{N}$ - Khawia rossittensis; $\mathbf{O}, \mathbf{P}$ - Khawia saurogobii; $\mathbf{Q}-$ Khawia sinensis; $\mathbf{R}$ - Monobothrium wageneri; $\mathbf{S}$ - Paracaryophyllaeus gotoi; $\mathbf{T}$ - Paraglaridacris limnodrili. Originals. Scale bars: A, D, I, K, L, O, $\mathrm{P}, \mathrm{S}=0.25 \mathrm{~mm} ; \mathrm{B}, \mathrm{C}, \mathrm{E}-\mathrm{H}, \mathrm{J}, \mathrm{M}, \mathrm{N}=0.5 \mathrm{~mm} ; \mathrm{Q}, \mathrm{R}=1 \mathrm{~mm} ; \mathrm{T}=0.1 \mathrm{~mm}$. 
3g. Scolex digitiform (Fig. 1R) Monobothrium wageneri Nybelin, 1922 Scolex digitiform, widened in posterior part, with oval to blunt end (Fig. 1R); testes begin at same level as or slightly anterior to anteriormost vitelline follicles (Fig. 3I).

4a. Anteriormost testes begin posterior to first vitelline follicles (Fig. 2K)

.......... Paracaryophyllaeus gotoi (Motomura, 1927) Scolex bulbate, wider than anterior part of body, with smooth margin, neck absent (Fig. 1S); vitelline follicles begin immediately posterior to scolex; testes begin posterior to first vitelline follicles (Fig. 2K).

4b. Anteriormost testes and vitelline follicles begin at approximately same level, posterior to neck (Fig. 3A) ........ Khawia armeniaca (Cholodkovsky, 1915) Scolex semi-bulbate, slightly wider than neck, with oval anterior end (Fig. 1K); anteriormost testes and vitelline follicles start at approximately same level, posterior to neck region (Fig. 3A).

5a. Anteriormost testes begin posterior to first vitelline follicles (Fig. 2A)

Atractolytocestus huronensis Anthony, 1958 Scolex bulboacuminate to almost montanate, with smooth margin (Fig. 1A); testes begin posterior to vitelline follicles (Fig. 2A).

5b. Anteriormost testes begin anterior to first vitelline follicles (Fig. 2B, C)

Atractolytocestus sagittatus

(Kulakovskaya et Akhmerov, 1965)

Scolex bulboacuminate, smooth (Fig. 1B) or with longitudinal grooves (Fig. 1C); testes begin anterior to vitelline follicles (Fig. 2B, C).

6a. Scolex slightly tapered anteriorly; neck absent (Fig. 1F, G)

Caryophyllaeides ergensi Scholz, 1990 and Caryophyllaeides fennica (Schneider, 1902)

Scolex cuneiform, slightly tapered anteriorly, with hemispheric, smooth anterior end, neck absent (Fig. 1F, G); testes begin posterior to anteriormost vitelline follicles (Fig. 2F, G).

Remarks: Slight differences among both species exist in the distribution and extent of the anteriormost vitelline follicles (less numerous medially in C. ergensi) and testes (begin more posteriorly in C. fennica); however, the main diagnostic feature is the extent of uterine loops, which may reach up to the midline of the body in C. ergensi (see Scholz 1990).

6b. Scolex not tapered anteriorly; neck present (Fig. 1E, N) 7

7a. First testes and vitelline follicles begin at approximately same level, immediately posterior to neck region (Fig. 2E)

Breviscolex orientalis Kulakovskaya, 1962 Scolex cuneiform, with curved anterior margin, only slightly wider than neck, with a few superficial grooves on dorsal and ventral margin (Fig. 1E); testes and first vitelline follicles begin just posterior to neck (Fig. 2E).

7b. First testes begin posterior to first vitelline follicles

8a. Scolex with anterior margin not curved, expanded laterally (Fig. 1N)

Khawia rossittensis (Szidat, 1937)

Scolex cuneiform, with blunt, uncurved anterior extremity, slightly expanded laterally (Fig. 1N); testes begin posterior to first vitelline follicles (Fig. 3E).

8b. Scolex with round anterior margin and prominent lateral expansions (Fig. 3D, H)

9a. Scolex short, with rounded lateral expansions; neck distinct (Fig. 3D) ....... Khawia parva (Zmeev, 1936) Scolex cuneiform to almost flabellate, short, laterally expanded, with distinct neck; anteriormost vitelline follicles begin far posterior to anterior edge of scolex; testes begin posterior to first vitelline follicles (Fig. 3D).

9b. Scolex with lateral expansions ("auricular"); neck indistinct (Fig. 3H)

... Monobothrium auriculatum Kulakovskaya, 1961 Scolex cuneiform, with auricular lateral expansions according to Kulakovskaya (1961); neck indistinct (Fig. 3H); vitelline follicles begin immediately posterior to scolex; testes begin posterior to first vitelline follicles (Fig. 3H).

10a. Scolex cuneicrispitate (flabellate with fimbriate anterior margin) (Fig. 1I)

.... Caryophyllaeus fimbriceps Annenkova-Chlopina, 1919

Scolex cuneicrispitate, with short indentations on anterior margin (Fig. 2I); anteriormost vitelline follicles begin anterior to first testes (Fig. 2I).

10b. Scolex cuneifimbriate (Fig. 1M)

Khawia japonensis (Yamaguti, 1934) Scolex cuneifimbriate, with fimbriate anterior margin, slightly wider than neck region (Fig. 1M); anteriormost vitelline follicles and testes start at approximately same level, slightly posterior to scolex (Fig. 3C).

10c. Scolex festoon-like, with deep folds on anterior margin (Fig. 1Q) ................ Khawia sinensis Hsü, 1935 Scolex festoon-like, deeply folded, markedly wider than neck region (Fig. 1Q); anteriormost vitelline follicles begin well posterior to scolex; testes usually begin posterior to first vitelline follicles (Fig. 3G).

11a. First vitelline follicles and testes begin at same level, immediately posterior to short neck region (Fig. 2H)

..... Caryophyllaeus brachycollis Janiszewska, 1951 Scolex flabellate, with very shallow indentations and many superficial grooves (Fig. 1H), slightly wider than short neck region; first vitelline follicles and testes begin immediately posterior to neck region, at approximately same level (Fig. 2H).

11b. Anteriormost vitelline follicles begin well posterior from edge of scolex; neck long; testes begin well posterior to first vitelline follicles (Figs. 2J, 3B) ........ 12 

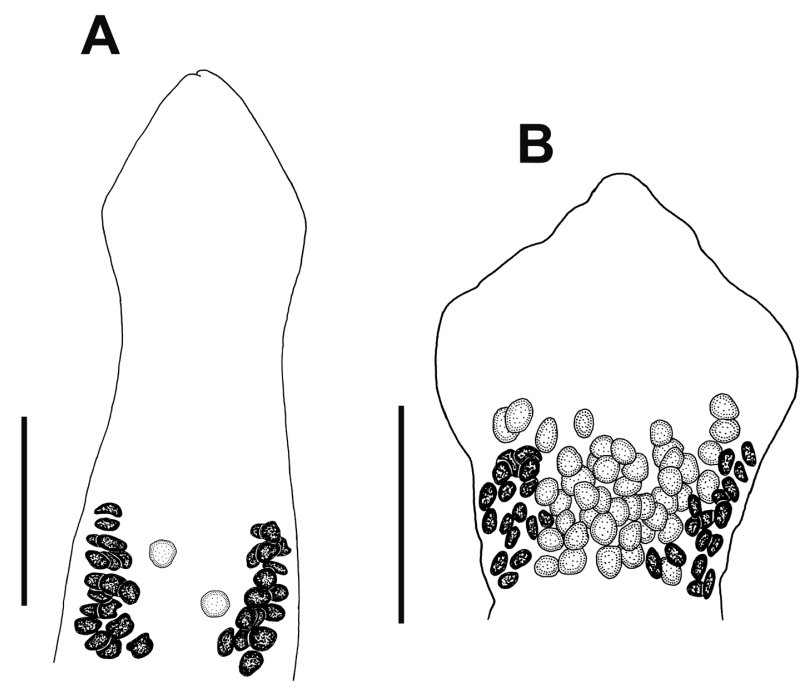

C
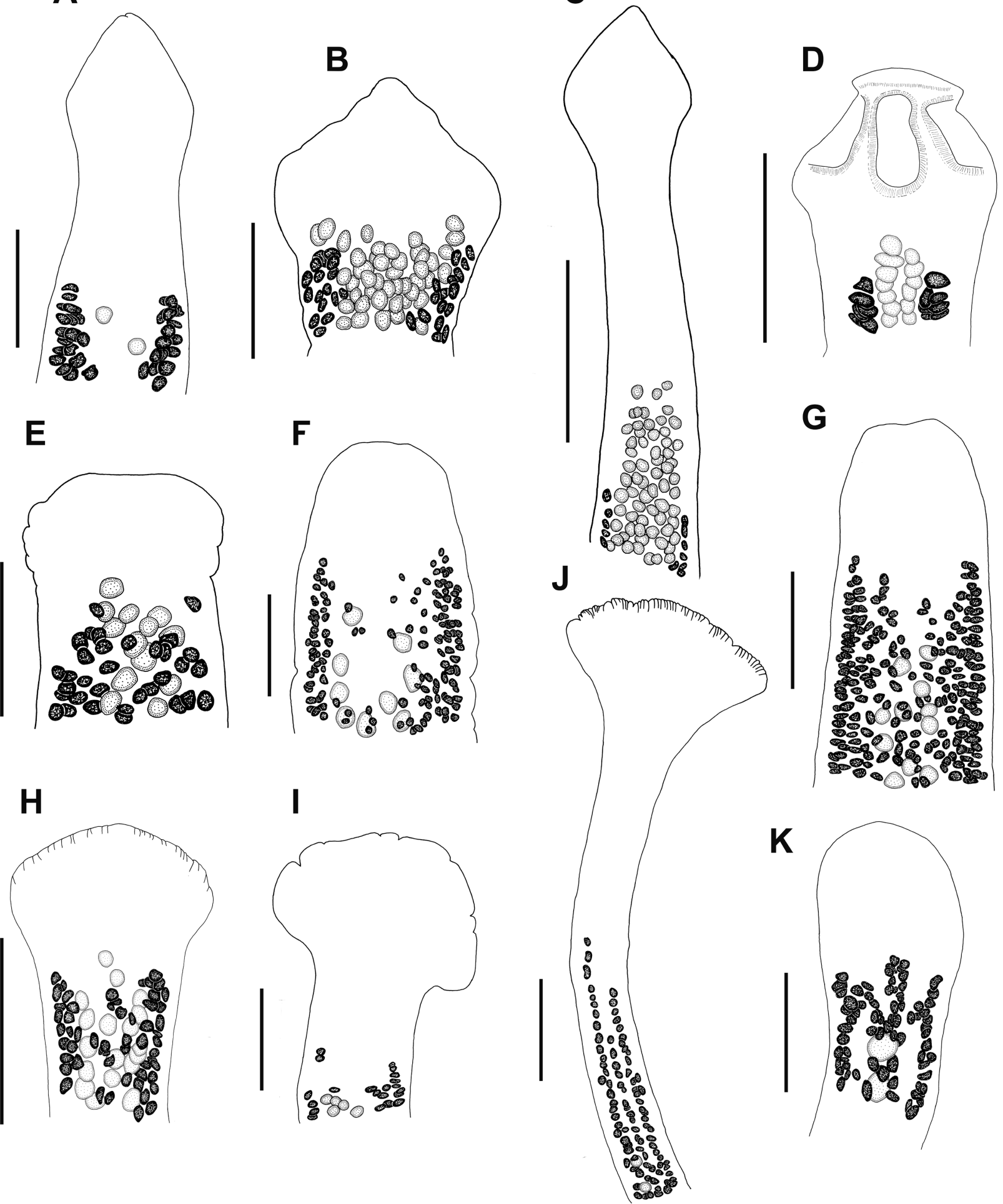

Fig. 2. Line drawings of the anterior parts of the Palaearctic species of Caryophyllidea showing the anteriormost vitelline follicles (black) and testes (stippled) I. A - Atractolytocestus huronensis; B, C - Atractolytocestus sagittatus; D - Archigetes sieboldi; $\mathbf{E}-$ Breviscolex orientalis; $\mathbf{F}$ - Caryophyllaeides ergensi; $\mathbf{G}$ - Caryophyllaeides fennica; $\mathbf{H}$ - Caryophyllaeus brachycollis; $\mathbf{I}$ - Caryophyllaeus fimbriceps; $\mathbf{J}$-Caryophyllaeus laticeps; $\mathbf{K}$ - Paracaryophyllaeus gotoi. Originals. Scale bars: A-C, E-J = $1 \mathrm{~mm}$; D, $\mathrm{K}=0.5 \mathrm{~mm}$. 
12a. Anterior margin of scolex with numerous, very shallow indentations; scolex about twice as wide as neck region (Fig. 1J)...

Caryophyllaeus laticeps (Pallas, 1781)

Scolex flabellate, anterior margin with numerous, shallow indentations; scolex about twice as wide as long neck region (Figs. 1J, 2J); anteriormost vitelline follicles begin well posterior to front edge of scolex; testes begin well posterior to first vitelline follicles (Fig. 2J).

12b. Anterior margin of scolex with indentations; scolex less than twice as wide as neck region (Fig. 1L) ..... Khawia baltica Szidat, 1942 Scolex flabellate, anterior margin with wrinkles, scolex less than twice as wide as neck region (Fig. 1L); anteriormost vitelline follicles begin well posterior to front edge of scolex; testes begin well posterior to first vitelline follicles (Fig. 3B).

Remarks: $K$. baltica and $C$. laticeps are somewhat similar in scolex morphology but they belong to different families (Lytocestidae and Caryophyllaeidae, respectively) and are markedly different in the morphology of genital organs, especially the extent of preovarian uterine loops (much longer in K. baltica compared to that in C. laticeps - see Scholz 1989) and the distribution of vitelline follicles alongside the lateral arms of the ovary (follicles present in the former species versus absent in C. laticeps) (Dubinina 1987, Scholz 1989, Protasova et al. 1990).

\section{DISCUSSION}

Scolex morphology and anterior extent of the testes and vitelline follicles of 20 species of caryophyllidean cestodes from cypriniform fishes (Cyprinidae and Cobitidae) in the Palaearctic Region that we consider to be valid were assessed as to their suitability for species identification. A comprehensive data set of three-dimensional characteristics of the scoleces of 18 taxa was provided for the first time using scanning electron microscopy (SEM). The main aim of the present study was to present comparative data on the scolex morphology of these cestodes based on the material processed by the same method (fixation with hot formaldehyde solution (= formalin) that ensures comparability of specimens collected from different hosts in different regions (see Appendix).

In the course of long-term studies on the helminth parasites of freshwater fishes throughout the Palaearctic Region (China, Czech Republic, Finland, Japan, Russia, and Slovakia), an extensive amount of caryophyllidean cestodes was collected and fixed in the same way. Evaluation of this material has revealed that all but one species have a high uniformity in the shape of their scoleces. Therefore, SEM pictures of scoleces of these tapeworms can be considered to document a specific characteristic of caryophyllidean species. The only exception is $\mathrm{A}$. sagittatus from Japan, in which two morphotypes, differing in the shape of the scolex, but also in the size of the body and anteriormost extent of vitelline follicles, were observed.
Further studies are needed to confirm conspecificity of these morphotypes or possible existence of two sibling (cryptic) species. A preliminary analysis of ITS sequences indicated that paralogues are present in this species (D. Tietz and T. Scholz - unpublished data), but more data are necessary for the assessment of possible relationships between the presence of paralogues and different morphotypes (see also Král'ová-Hromadová et al. 2010).

A fairly different situation in scolex variability was observed among specimens from museum collections, which were not fixed with hot formalin. In these specimens, a wide variability in scolex shape and size was observed (e.g., in Khawia armeniaca and Monobothrium wageneri). It remains unclear whether such a higher degree of intraspecific variation reflects natural morphological variability of individual taxa or is mainly influenced by different processing and fixation methods. Based on our experience with several groups of fish cestodes and trematodes as well (Scholz et al. 2001), the latter option seems to be rather probable.

Besides scolex morphology, the present study assessed suitability of the comparative anterior extent of the testes and vitelline follicles for species identification. It has been documented that this feature is of taxonomic value (Kulakovskaya 1961, Kennedy 1965, Mackiewicz 1972, 2003, Dubinina 1987, Scholz 1989, Protasova et al. 1990), but this is the first assessment of its validity in a large sample of cestodes processed with the same method. Unlike scolex shape, the mutual position of the testes and vitelline follicles and their distance from the anterior edge of the scolex may vary to some extent. However, since most species exhibit relatively stable patterns in this characteristic, it thus can be used for identification of most caryophyllidean species from the Palaearctic Region.

An early attempt to propose scolex morphology as a useful tool for classification of caryophyllideans and the identification of species from North America was made by Hunter (1930). Additional scolex traits of use in identifying species parasitizing suckers (Cypriniformes: Catostomidae) in the Nearctic Region were proposed by Calentine (1962), McCrae (1962), Mackiewicz (1963, 1968, 1972), and Mackiewicz and McCrae (1965). A more extensive comparison of scolex morphology in caryophyllideans showed their considerable morphological diversity and demonstrated dependence of the scolex shape and size on fixation method (Mackiewicz 1972, 1994, Chubb et al. 1987, Protasova et al. 1990).

Detailed information on the scolex morphology of the taxa parasitic in cypriniform fish in Central Europe was provided by Scholz (1989), who also used both light and scanning electron microscopy, as did Ibraheem and Mackiewicz (2006), who described the morphology of the scolex of Wenyonia virilis Woodland, 1923, a parasite of the mochokid catfish Synodontis schall (Bloch et Schneider) from Egypt. However, almost none of the descrip- 
A

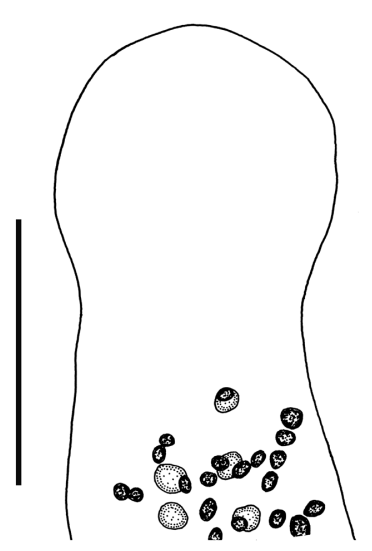

E

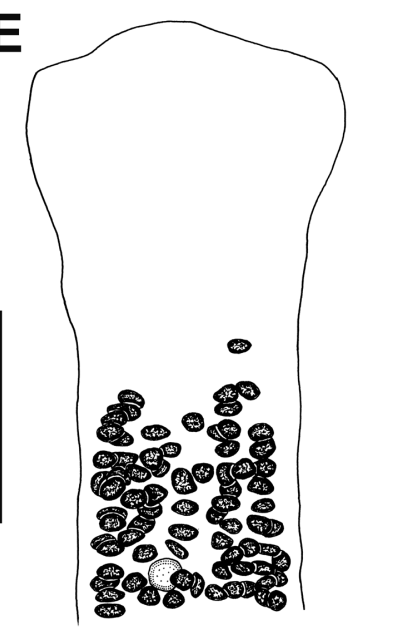

F

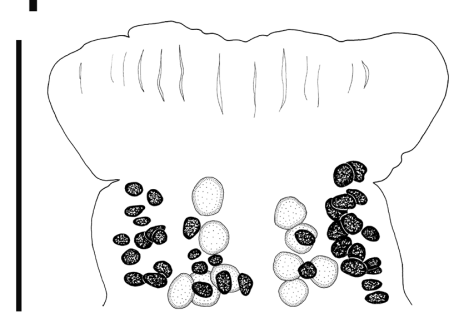

B

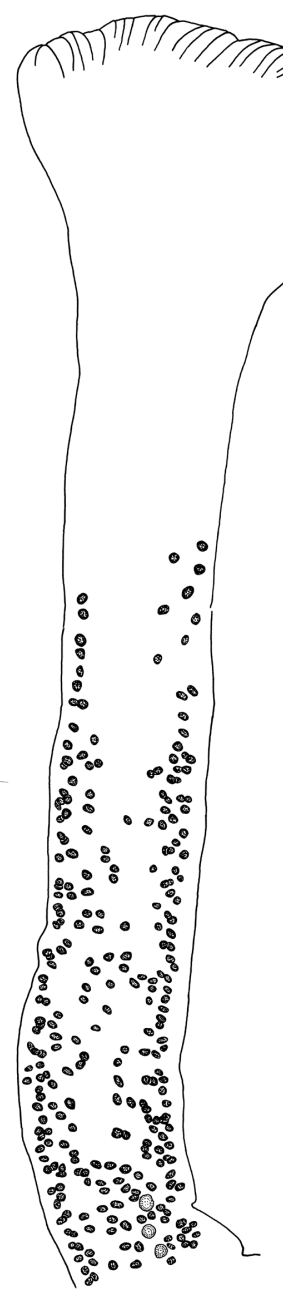

C

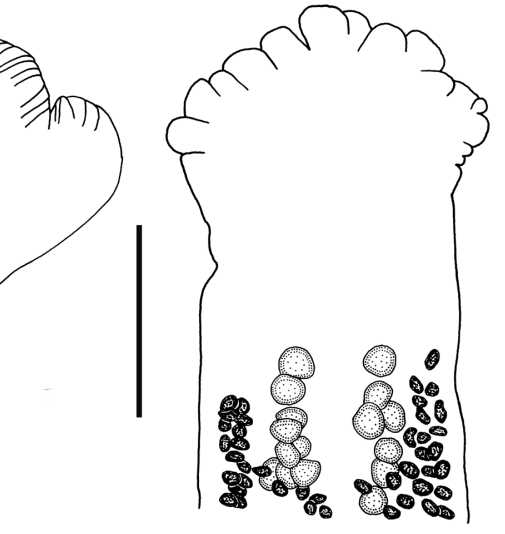

G

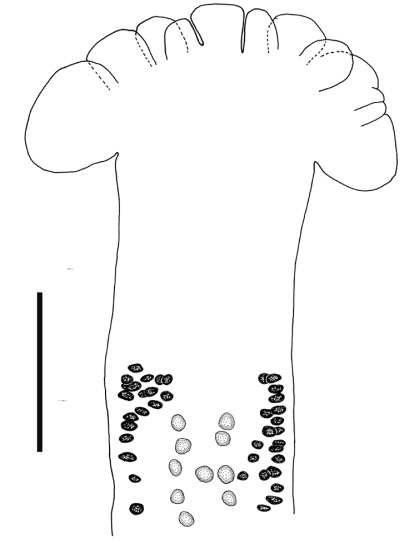

H

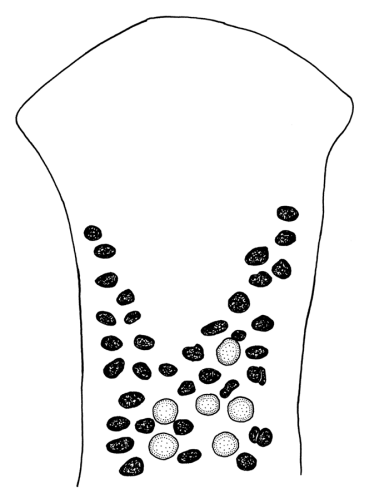

D
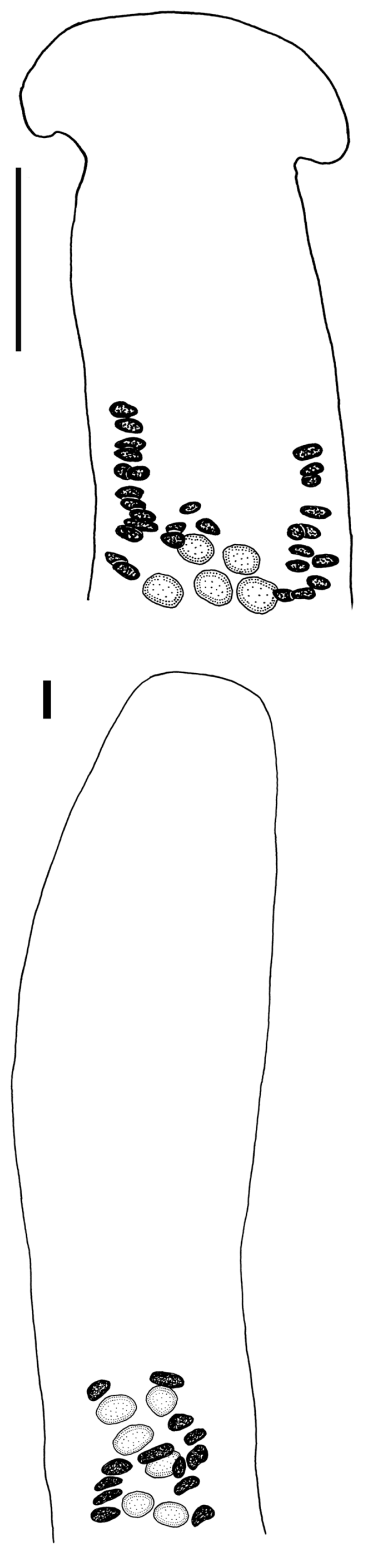

Fig. 3. Line drawings of the anterior parts of the Palaearctic species of Caryophyllidea showing the anteriormost vitelline follicles (black) and testes (stippled) II. A - Khawia armeniaca; $\mathbf{B}$ - Khawia baltica; C-Khawia japonensis; D - Khawia parva; $\mathbf{E}$ - Khawia rossittensis; F - Khawia saurogobii; $\mathbf{G}$ - Khawia sinensis; H - Monobothrium auriculatum (according to Kulakovskaya 1961); I - Monobothrium wageneri. Originals except for $\mathrm{H}$. Scale bars $=1 \mathrm{~mm}$.

tions of caryophyllidean taxa contain scanning electron micrographs of their scoleces.

According to Mackiewicz (2003 - see Table II), two basic scolex types exist among caryophyllideans; 24 of the currently recognized genera (i.e., 59\%) possess afossate scoleces and 17 genera (i.e., 41\%) possess fossate scoleces. The present study has also demonstrated a great variety of scolex types in caryophyllidean cestodes from the Palaearctic Region, with several scolex types present within two most specious genera, i.e. Khawia Hsü, 1935 and Caryophyllaeus Gmelin, 1790. In these genera, species-specific differences exist mainly in the form or type of scolex margin.

No material was available for Monobothrium auriculatum, but the figure of its scolex was re-drawn from the original description (Kulakovskaya 1961) and the species was included in the key. In contrast, taxa of uncertain taxonomic status or doubtful validity, namely Caryophyllaeus syrdarjensis Skrjabin, 1913 described from the barbel Schizothorax intermedius McClelland from Turkestan, 
and two species of Archigetes reported mainly from tubificid oligochaetes (Kennedy 1965), were excluded from the present study.

There is virtually no key to all Palaearctic caryophyllidean cestodes because the most comprehensive ones, i.e. those of Kulakovskaya (1961), Dubinina (1987) and Protasova et al. (1990), are outdated and not accessible for everyone (all were written in Russian). In addition, placement of genera to individual families is based on the position of vitelline follicles in relation to the inner longitudinal musculature (Mackiewicz 1994). This requires preparation of good-quality cross-sections, which may impede routine identification. The key to Palaearctic caryophyllideans presented herein is aimed at facilitating routine identification, regardless of family. However, some taxa cannot be differentiated merely on the basis of their scoleces and anteriormost vitelline follicles and testes and, therefore, other characteristics important for reliable identification of species must be considered. These include, among others, the shape of the ovary (species of Caryophyllaeides and Khawia), the anterior extent of the uterus (Caryophyllaeides), size and shape of the cirrussac (Caryophyllaeus), the number and position of testes (Atractolytocestus), and presence/absence of vitelline follicles along ovarian arms (Khawia). Despite certain limitations in differentiation of a few taxa possessing a similar scolex, such as Atractolytocestus and Caryophyllaeides, the preliminary key may serve as a useful tool for identification of most Palaearctic caryophyllideans. We have found it a helpful tool for species identification and a partial step in the systematic revision of caryophyllidean tapeworms that is in progress.

\section{APPENDIX}

Many years ago, two of the present authors (T. S. and V. H.) attempted to use specimens fixed in different ways in studies on the taxonomy of cestodes parasitic in freshwater teleost fishes. Different fixatives, such as cold $4 \%$ formalin (or 10\% formol), ethanol (70\%) (including shaking the worms within a vial) and Berland's fluid were used and tapeworms were fixed while flattened under pressure between two glasses, after being relaxed in water or saline to avoid contraction or were fixed in vital stains. All of these procedures failed to produce suitable results because they invariably resulted in producing worms with artifacts such as artificial shapes and sizes, unnaturally flattened, contracted and/or deformed. Relaxing in water or saline appeared also to be unsuitable, because the worms were unnaturally extended, their tegument detached and internal tissues were decomposed; genital organs had loose structure, cells were vacuolated and organs such as testes and vitelline follicles were not clearly delimited. A similar observation was made by Kennedy (1965 - p. 441) who claimed "If specimens are allowed to relax for some time in water before fixation the shape of the scolex alters and the bothria become far less evident and may disappear". Since 1995, the fixation method used by cestodologists of the Natural History Museum in Geneva, Switzerland (C. Vaucher and A. de Chambrier), fixation with hot $4 \%$ formalin, has been applied during studies on the systematics of proteocephalidean tapeworms (see Scholz and Hanzelová 1998, Scholz et al. 1998). This method is very simple, suitable even for field sampling, and it has provided by far the best results in our studies on cestodes of freshwater and marine teleost fishes. We have found that samples of tapeworms from the same hosts were always fairly uniform, homogeneous in shape of the body, including the scolex, notwithstanding worms' size and state of maturity.

This fixation also made it possible to obtain comparable samples of tapeworms collected by different persons and from different hosts and regions. The tegument of these worms, including microtriches and armature of terminal genitalia, remains intact, thus making material suitable for SEM observations (see, e.g., Levron et al. 2008). In addition, tissues of the worms, including parenchymatous organs, are well preserved and thus suitable for staining as permanent mounts, SEM observations (see Scholz et al. 1998, Kuchta et al. 2008) and histological sections (de Chambrier et al. 2008, 2009).

Suitability of this fixation method has already been documented by a number of taxonomic and morphological studies on proteocephalidean (see, e.g., de Chambrier and Vaucher 1997, 1999, Scholz and Hanzelová 1998, de Chambrier et al. 2007, 2008, 2009, de Chambrier and Scholz 2008, Scholz et al. 2009) and bothriocephalidean cestodes (e.g., Kuchta et al. 2008, 2009a, b). A large-scale sampling of caryophyllidean cestodes in Africa, Europe, Asia (Japan and India) and North America, carried out by the present authors since 1995, has confirmed suitability of this fixation method also for caryophyllideans.

Acknowledgements. Valuable comments and helpful suggestions of two anonymous reviewers are greatly appreciated. The authors also thank Roman Kuchta, Marta Špakulová and Ludmila Turčeková for help with collecting material for this study. Special thanks are due to Alex Galkin, Zoological Institute, Russian Academy of Sciences, St. Petersburg, Larisa V. Filimonova, Ekaterina N. Protasova, Parasitological Institute, RAS, Moscow, Larisa G. Poddubnaya, Institute of Biology of Inland Waters, Borok, all from Russia, and František Moravec, Institute of Parasitology AS CR, České Budějovice, Czech Republic for access to helminthological collections and lending material of caryophyllideans, and Martina Tesařová, Laboratory of Electron Microscopy, Institute of Parasitology for excellent technical assistance. Samples of several species from Biwa Lake were taken during short stays of T.S. in Japan in 2001 and 2007, supported by Biwa Lake Museum Research Projects K00-05 and S06-02, directed by Mark J. Grygier. M.O. is grateful to Bing Wen Xi for help in collecting material of Khawia saurogobii during his short stay in Wuhan, China in 2009 and for financial support to the National Science Foundation, USA (PBI award Nos. 0818696 and 0818823). This study was supported by the Grant Agency of the Czech Republic (project No. 524/08/0885 to T.S.) and the Institute of Parasitology (projects Nos. Z60220518 and LC522), Scientific Grant Agency of the Slovak Republic VEGA (project No. 2/7192/27), Slovak Research and Development Agency (project No. LPP 0171-09) and European Commission, SYNTHESYS Projects: DE-TAF-127, HU-TAF-300, AT-TAF-411, GB-TAF-1135, FR-TAF-1139, and DK-TAF-2354. 


\section{REFERENCES}

Bauer O.N., Musselius V.A., Strelkov Y.A. 1973: Diseases of pond fishes. Israel Programme for Scientific Translations, Jerusalem, $220 \mathrm{pp}$

Calentine R.L. 1962: Archigetes iowensis sp. n. (Cestoda: Caryophyllaeidae) from Cyprinus carpio L. and Limnodrilus hoffmeisteri Claparède. J. Parasitol. 48: 513-524.

Chubb J.C., Pool D.W., Veltkamp C.J. 1987: A key to the species of cestodes (tapeworms) parasitic in British and Irish freshwater fishes. J. Fish Biol. 31: 517-543.

de Chambrier A., Mariaux J., Sène A., Mahmoud Z.N., Scholz T. 2008: Sandonella sandoni (Lynsdale, 1960), an enigmatic and morphologically unique cestode parasitic in the osteoglossiform fish Heterotis niloticus in Africa. J. Parasitol. 94: 202-211.

de Chambrier A., Scholz T. 2008: Tapeworms (Cestoda: Proteocephalidea) of firewood catfish Sorubimichthys planiceps (Siluriformes: Pimelodidae) from the Amazon River. Folia Parasitol. 55: 17-28.

de Chambrier A., Scholz T., Beletew M., Mahmoud Z.N. 2007: Redescription of Proteocephalus sulcatus (Klaptocz, 1906) (Cestoda: Proteocephalidea), a poorly known parasite of Clarotes laticeps (Pisces: Siluriformes) in the Sudan. Rev. Suisse Zool. 114: 693-702.

de Chambrier A., Scholz T., Beletew M., Mariaux J. 2009: A new genus and species of proteocephalidean (Cestoda) from Clarias catfishes (Siluriformes: Clariidae) in Africa. J. Parasitol. 95: $160-168$.

de Chambrier A., Vaucher C. 1997: Revision of the cestodes (Monticelliidae) described by Woodland (1934) in Brachyplatystoma filamentosum with a redefinition of the genera Endorchis Woodland, 1934, and Nomimoscolex Woodland, 1934. Syst. Parasitol. 37: 219-233.

de Chambrier A., Vaucher C. 1999: Proteocephalidae and Monticelliidae (Eucestoda: Proteocephalidea) parasites of freshwater fishes in Paraguay, with description of a new genus and ten new species. Rev. Suisse Zool. 106: 165-240.

Dubinina M.N. 1987: [Class tapeworms - Cestoda Rudolphi, 1808.] In: O.N. Bauer (Ed.) [Key to the Parasites of Freshwater Fishes of the USSR.], Nauka, Leningrad, pp. 5-76. (In Russian.)

Hunter G.W. 1930: Studies on the Caryophyllaeidae of North America. Illinois Biological Monographs 11 (1927), University of Illinois, Illinois, $186 \mathrm{pp}$.

IbraheEm M.H., Mackiewicz J.S. 2006: Scolex development, morphology and mode of attachment of Wenyonia virilis Woodland, 1923 (Cestoidea, Caryophyllidea). Acta Parasitol. 51: 51-58.

Kennedy C.R. 1965: Taxonomic studies on Archigetes Leuckart, 1878 (Cestoda: Caryophyllaeidae). Parasitology 55: 439-451.

Králová-Hromadová I., Štefka J., Špakulová M., Orosová M., Bombarová M., Hanzelová V., Bazsalovicsová E., Scholz T. 2010: Intraindividual ITS1 and ITS2 ribosomal sequence variation linked with multiple rDNA loci: a case of triploid Atractolytocestus huronensis, the monozoic cestode of common carp. Int. J. Parasitol. doi:10.1016/j.ijpara.2009.07.002.

Kuchta R., Scholz T., Bray R.A. 2008: Revision of the order Bothriocephalidea Kuchta, Scholz, Brabec \& Bray, 2008 (Eucestoda) with amended generic diagnoses and keys to families and genera. Syst. Parasitol. 71: 81-136.

Kuchta R., Scholz T., Justine J.-L. 2009a: Two new species of Bothriocephalus Rudolphi, 1808 (Cestoda: Bothriocephalidea) from marine fish off Australia and New Caledonia. Syst. Parasitol. 73: 229-238.

Kuchta R., Scholz T., Vlčková R., Říha M., Walter T., Yuniar A.T., Palm H.W. 2009b: Revision of tapeworms (Cestoda: Both- riocephalidea) from lizardfish (Saurida: Synodontidae) from the Indo-Pacific region. Zootaxa 1977: 55-67.

Kulakovskaya O.P. 1961: [Materials on the fauna of Caryophyllaeidae (Cestoda, Pseudophyllidea) of the Soviet Union.] Parazitol. Sb. 20: 339-355. (In Russian.)

Levron C., Scholz T., Dezfuli B.S. 2008: Ultrastructure of microtriches on the scolex of Cyathocephalus truncatus (Cestoda: Spathebothriidea). Folia Parasitol. 55: 309-312.

Mackiewicz J.S. 1963: Monobothrium hunteri sp.n. (Cestoidea: Caryophyllaeidae) from Catostomus commersoni (Lacépède) (Pisces: Catostomidae) in North America. J. Parasitol. 49: 723-730.

Mackiewicz J.S. 1968: Two new caryophyllaeid cestodes from the spotted sucker, Minytrema melanops (Raf.) (Catostomidae). J. Parasitol. 54: 808-813.

Mackiewicz J.S. 1972: Caryophyllidea (Cestoidea): a review. Exp. Parasitol. 31: 417-512.

Mackiewicz J.S. 1981: Caryophyllidea (Cestoidea): evolution and classification. Adv. Parasitol. 19: 139-206.

Mackiewicz J.S. 1994: Order Caryophyllidea van Beneden in Carus, 1863. In: L.F. Khalil, A. Jones and R.A. Bray (Eds.), Keys to the Cestode Parasites of Vertebrates. CAB International, Wallingford, pp. 21-43.

Mackiewicz J.S. 2003: Caryophyllidea (Cestoidea): molecules, morphology and evolution. Acta Parasitol. 48: 143-154.

Mackiewicz J.S., McCrae R.C. 1965: Biacetabulum biloculoides n. sp. (Cestoidea: Caryophyllaeidae) from Catostomus commersoni (Lacépède) in North America. Proc. Helminthol. Soc. Wash. 32: 225-228.

MCCRAE R.C. 1962: Biacetabulum macrocephalum sp. n. (Cestoda: Caryophyllaeidae) from the white sucker Catostomus commersoni (Lacépède) in northern Colorado. J. Parasitol. 48: 807-811.

Oros M., Hanzelová V., Scholz T. 2009: Tapeworm Khawia sinensis: Review of the introduction and subsequent decline of a pathogen of carp, Cyprinus carpio. Vet. Parasitol. 164: 217-222.

Protasova E.P., Kuperman B.I., Roitman V.A., Poddubnaya L.G. 1990: [Caryophyllid Tapeworms of the Fauna of USSR.] Nauka, Moscow, 237 pp. (In Russian.)

Scholz T. 1989: Amphilinida and Cestoda, parasites of fish in Czechoslovakia. Acta Sci. Nat. Brno 23(4): 1-56.

Scholz T. 1990: Caryophyllaeides ergensi sp. n. (Cestoda: Caryophyllidea) from Leuciscus leuciscus baicalensis from Mongolia. Folia Parasitol. 37: 231-235.

Scholz T., Aguirre-Macedo M.L., Salgado-Maldonado G. 2001: Trematodes of the family Heterophyidae (Digenea) in Mexico: a review of species and new host and geographical records. J. Nat. Hist. 35: 1733-1772.

Scholz T., de Chambrier A., Beletew M., Mahmoud Z.N. 2009: Redescription of Proteocephalus glanduligerus (Cestoda: Proteocephalidea), a parasite of clariid catfishes in Africa with a unique glandular apical organ. J. Parasitol. 95: 443-449.

Scholz T., Drábek R., Hanzelová V. 1998: Scolex morphology of Proteocephalus tapeworms (Cestoda: Proteocephalidae), parasites of freshwater fish in the Palaearctic Region. Folia Parasitol. 45: 27-43.

Scholz T., Hanzelová V. 1998: Tapeworms of the Genus Proteocephalus Weinland, 1858 (Cestoda: Proteocephalidae), Parasites of Fishes in Europe. Studie AV ČR, No. 2/98, Academia, Prague, $118 \mathrm{pp}$.

Williams H., Jones A. 1994: Parasitic Worms of Fish. Taylor and Francis, London and Bristol, 593 pp.

Accepted 19 October 2009 